\title{
SEXUAL DIMORPHISM IN THE GROWTH PATTERN OF BROILERS UNDER DIFFERENT DIETARY AND HOUSING CONDITIONS
}

\author{
E.A.O. LASEINDE AND J.A. OLUYEMI
}

Department of Animal Production and Health, Federal University of Technology, Akure, Nigeria

Received 28 August, 1995; Accepted 09 August, 1996

\section{ABSTRACT}

Two hundred and seventy day old broiler chicks were randomly distributed among three dietary treatments (iso-nitrogenous high and low energy straight-run diets and a conventional broiler diet) and two housing conditions (the cage and deep litter) to study the comparative growth patterns between the male and female broilers. Each treatment was replicated thrice at 15 birds per replicate. The chicks were raised for 8 weeks. There were significant interactions $(P<0.05)$ between age, diet, housing location and sex. The male broilers had significantly $(P<0.05)$ higher body weight gains than the females especially at the finisher phase. While the females performed better on high energy diet at both phases, the males responded to low energy diet at the starter phase and high energy at the finisher, hence a narrower male: female divergence ratie at the finisher phase. Generally, location had no significant effect $(P>0.05$ ) on body weight gains ( $215.0 \mathrm{~g}$ vs 214.3g/bird/wk - cage vs floor). However, males gained slightly more weight in the cage while females gained slightly more on deep litter. Both recorded higher gains on the floor at the starter phase and in the cage at the finisher period. Coefficient of variation was respectively lower for the male broilers, birds in the cage, birds at the finisher phase and lowest for birds on conventional diet. Feed consumption was significantly higher $(P<0.05)$ for low energy diet $(68.9$ vs $65.1 \mathrm{~g} / \mathrm{bird} / \mathrm{day}$ ) as well as by birds in the cage (69.4 vs $64.5 \mathrm{~g} / \mathrm{bird} / \mathrm{day}$ ) with correspondingly lower utilization rate.

Key Words: Sexual dimorphism, broilers, growth patterns, diets, housing.

\section{INTRODUCTION}

Sexual dimorphism is a natural phenomenon in all growing animals characterised by the manifestation of visible differences between the male and female species. In the domestic chiken, this is observed from the body weight gains, size, shape and behaviour of the birds. Sharma $e t$ al. (1983) reported that body weight at hatching was significantly affected by sex and strain of chickens. Whiting and Pesti (1983) indicated that male broilers were heavier than the females at hatching while Verma et al. (1983) gave the average body weight at hatching as $40.31 \mathrm{~g}$ for male and $36.6 \mathrm{~g}$ for the female. At the growing and finishing stages also, t'ie males were heavier than the females (Thangaraju et al., 1983; Polanco and Vigil, 1984; Keshri et al., 1985). Mark (1985; 1986; 1987) reported various findings on sexual dimorphism in relation to body weight, feed and water intakes of broilers. He found that the differences between the sexes in body weight which were observed post-hatch became significant after four days of age and increased thercafter in a more or less linear fashion with age. Also at $\mathbf{1 4}$ days of age, males were $7 \%$ heavier than the females and the males consumerl more feed and water than the females.

Generally, growth performance of broilers depends on many factors, amongst which nutrition and housing are of major considerations. These factors may similarly affect the sexual dimorphism of the birds growthwise. Babatunde and Fetuga (1976) recommended that the broiler starter and finisher diets should have no less than 24 and $18 \% \mathrm{CP}$ levels respectively. Summers and Lesson (1984) reported that dietary energy level had less effect on weight gain in male than the female broilers. Females usually deposit more abdominal fat than males (Pandey et al., 1985). High energ level in the diet depresses feed intake but improves feed 


\section{LASEINDE AND OLUYEMI}

utilization (Olomu, 1976; Reece et al., 1984; Mendes afd Cury, 1986). Considering the effect of housing on broiler performance, better weight gains were reported from birds reared in cages than the deep litter (Leeson and Summers, 1985; Rajmane and Kulkarni, 1985; Ulmek, 1986). Sexual dimorphism has direct effect on the finishing body weight of broilers with males being heavier than females, and therefore on the total available meat at market age. This is further influenced by nutrition and housing conditions. This study was therefore undertaken to determine the comparative growth patterns of the male and female broilers under three different dietary regimes and two housing conditions (cage verse floor) and at different ages during the eight week growing period. This was aimed at providing basic information on the most suitable of the experimental conditions that would enhance the performance of male and female broilers respectively. The research also compared the coefficients of variation (C.V) between the body weights. Determination of the C.V. was aimed at investigating and comparing the uniformity of growth of the individual sexes under each of the treatment conditions.

\section{MATERIALS AND METHODS}

A total of two hundred and seventy unsexed day old broiler chicks were randomly distributed under three dietary treatments and two housing locations in a completely

TABLE 1: COMPOSITION OF EXPERIMENTAL DIETS FED TO THE BROILERS

\begin{tabular}{|c|c|c|c|c|c|}
\hline \multirow[b]{2}{*}{ lngredients } & \multirow[b]{2}{*}{ Diet 1} & \multicolumn{2}{|c|}{ Percentage in ration } & & \multirow[b]{2}{*}{ Diet 3b } \\
\hline & & Diel 2 & Diet 3a & & \\
\hline Maize & 51.90 & 53.00 & 46.90 & & 54.50 \\
\hline Groundnut cake & 25.50 & 26.00 & 29.50 & & 25.50 \\
\hline Fish meal & 2.50 & 3.50 & 5.00 & & 2.50 \\
\hline Palm Kernel meal & 6.00 & 5.00 & 5.00 & & 5.00 \\
\hline Brewers dried grain & 9.50 & 3.20 & 9,00 & & 3.20 \\
\hline Palm Oil & - & 4.70 & - & & 4.70 \\
\hline Bone meal & 2.75 & 2.75 & 2.75 & & 2.75 \\
\hline Oyster shell & 0.75 & 0.75 & 0.75 & & 0.75 \\
\hline *Vit-Min premix & 0.25 & 0.25 & 0.25 & & 0.25 \\
\hline Salt & 0.50 & 0.50 & 0.50 & & 0.50 \\
\hline DL-Methionine & 0.15 & 0.15 & 0.15 & & 0.15 \\
\hline \multirow[t]{2}{*}{ Lysine } & 0.20 & 0.20 & 0.20 & & 0.20 \\
\hline & 100.00 & 100.00 & 100.00 & & 100.00 \\
\hline \multicolumn{6}{|l|}{ Calculated Analysis } \\
\hline \multicolumn{6}{|l|}{ Metabolizable energy } \\
\hline (Kcal/kg diet) & 2844 & 3204 & 2810 & 3201 & \\
\hline Crude Protein (\%) & 21.00 & 20.99 & 24.09 & 20.02 & \\
\hline Crude Fybre (\%) & 4.95 & 3.63 & 4.83 & 3.63 & \\
\hline Calcium (\%) & 1.19 & 1.24 & 1.35 & 1.74 & \\
\hline Available Phoshorus (\%) & 0.56 & 0.56 & 0.64 & 0.53 & \\
\hline Lysine (\%) & 0.92 & 0.91 & 1.06 & 0.86 & \\
\hline Methionine (\%) & 0.45 & 0.44 & 0.50 & 0.43 & \\
\hline Cystine $(\%)$ & 0.31 & 0.29 & 0.34 & 0.29 & \\
\hline Methione + Cystine (\%) & 0.76 & 0.73 & 0.84 & 0.72 & \\
\hline
\end{tabular}




\section{SEXUAL DIMORPHISM VS}

randomised design. Each treatment was replicated thrice and 15 birds were provided per replicate. The chicks were unsexed in order to determine their individual performance in mixed-sex management condition typical of Nigeria.

The formulated dietary treatments (Table 1) consisted of two straight-run isonitrogenous (21\% crude protein) low and high energy broiler diets (2844 and $3204 \mathrm{Kcal} / \mathrm{kg}$ diet). The third diet was a conventional one serving as control and it consisted of starter and finisher broiler mashes (Diets $3 a$ and $3 b$ ). The housing treatments provided for the birds were equidimensional cages and deep litter pens. Feed and water were provided ad libitum. Other management practices e.g. vaccination and medications were uniformly given to all the experimental birds. The birds were leg-tagged and weighed individually every week. The feed consumed was also determined weekly.

At the end of the study, the male and female birds were clearly identified and the progressive data from each sex were grouped separately under each replicate and treatment for statistical analysis. The data were analysed for variance of body weight gains according.to Snedecor and Cochran (1976). The male: female divergence ratio for body weight gains was calculated by dividing the male with the female values. The coefficients of variation (C.V.) for body weights were also computed for the male and female broilers separately every week under each treatment. The average intake and utilization of feeds were determined for the mixed sexes.

\section{RESULTS AND DISCUSSION}

Sex and age had highly significant $(P<0.01)$ effects on body weight gains of the broilers during the 8-week growing period. Diet also had a significant effect $(\mathrm{P}<0.05)$. Effect of location on body weight gains was generally not statistically significant $(P>0.05)$ when both sexes were considered together. There were significant interactions $(\mathrm{P}<0.05)$ between combinations of age, diet, location and sex except Diet $x$ Location and Location $x$ Sex.

\section{GROWTH OF BROILERS}

\section{Effect of Ags}

Divergence in body weight gains (BWG) between the male and female broilers increased with age (Table 2) and became more pronounced at the finishing period (5-8 weeks). Significant differences between the sexes in BWG during the starter phase occured at tha 2nd and 4th weeks. Throughout the knisher phase, there were differences $(P<0.01)$ in the weekly BWG between the sexes. The divergence ratios (DR) were equally high, reaching the peak of 1.328 at the 8th week. This has shown that sexual dimorphism in BWG increase gradually and progressively from the starter phase and becomes widest at the finisher stage.

\section{Effect of Diets}

The difference in BWG between the male and $f$ male broilers under each of the three diets was higly significantly $(P<0.01)$ for the 8 -week growing period. The male in each case was significant superior to the female (Table 3 ). The highest weight gains were recorded for either sex on the high energy diet (Diet 2). Similarly, the DR between the male and female broiler was smaller on Diet 2. This implies that, on the diet, the sexual dimorphism was minimal. The high energy diet had greater effect on the female broilers. This supports the report of Summers and Leeson (1984). The close divergence in BWG between male and female broilers on the high energy diet might be explained as due to the female broilers' ability to deposit more abdominal fat than males when fed high energy diet (Mendonca, 1983; Summers and Leeson, 1984; Deaton and Lott, 1985 and Pandey et al., 1985).

From this result, it will be expendient to use high energy diet, if it is economical, to reduce the body weight differences between the male and female broilers at market age if it is so desired. However, since the effect of the high energy ration is prodeminantly on the female, it might not be worth the extra cost of increasing the energy level of the diet. The lower energy diet (Diet 1) would be preferred over the other two from the result of this 


\section{LASEINDE AND OLUYEMI \\ TABLE 2: BODY WEIGH CANS AND MALE/FEMALE DIVERGENCE RATIOS FOR BROILERS AT VARIOUS AGES.}

\begin{tabular}{lllll}
\hline & & \multicolumn{2}{l}{ Mean body weight gains (g/bird/wk) } & D.R $^{2}$ \\
\hline 1 & Male & Female & S.E $^{1}$ & 1.060 \\
2 & 68.0 & 64.2 & 1.94 & 1.125 \\
3 & $142.4^{\mathrm{a}}$ & $126.6^{\mathrm{b}}$ & 4.13 & 1.102 \\
4 & $140.2^{\mathrm{a}}$ & 127.2 & 6.40 & 1.182 \\
5 & $196.4^{\mathrm{a}}$ & $166.3^{\mathrm{b}}$ & 9.47 & 1.214 \\
6 & $294.8^{\mathrm{a}}$ & $242.8^{\mathrm{b}}$ & 10.14 & 1.289 \\
7 & $319.7^{\mathrm{a}}$ & $247.9^{\mathrm{b}}$ & 9.71 & 1.268 \\
8 & $295.8^{\mathrm{a}}$ & $233.1^{\mathrm{b}}$ & 9.86 & 1.328 \\
\hline
\end{tabular}

${ }^{1} \mathrm{~S} . \mathrm{E}=$ Standard Error

${ }^{2}$ D.R = Divergence Ratio

$\mathrm{ab}=$ Means having different superscripts on the same row are significantly different $(\mathrm{P}<0.01)$

TABLE 3: BODY WEIGHT GAINS AND MALE/FEMALE DIVERGENCE RATIOS ON DIFFERENT DIETS AT VARIOUS GROWING PHASES OF BROILER CHICKENS.

\begin{tabular}{|c|c|c|c|c|c|}
\hline \multirow[b]{2}{*}{ Phase } & \multirow[b]{2}{*}{ Diet } & \multirow[b]{2}{*}{ Male } & \multicolumn{3}{|c|}{ Mean body weight gains (o/bird/wk) } \\
\hline & & & Female & S.E. & D.R \\
\hline \multirow[t]{3}{*}{ Starter (0-4 weeks) } & 1 & $136.9^{\mathrm{a}}$ & $119.8^{b}$ & 6.92 & 1.142 \\
\hline & 2 & 134.5 & 124.7 & 6.85 & 1.079 \\
\hline & 3 & $138.9^{\mathrm{a}}$ & $118.7^{b}$ & 6.50 & 1.170 \\
\hline \multirow[t]{3}{*}{ Finisher ( $5-8$ weeks) } & 1 & $292.5^{\mathrm{a}}$ & $227.0^{\mathrm{b}}$ & 8.32 & 1.289 \\
\hline & 2 & $295.3^{\mathrm{a}}$ & $246.6^{\mathrm{b}}$ & 8.11 & 1.197 \\
\hline & 3 & $289.7^{3}$ & $216.0^{\mathrm{b}}$ & 11.33 & 1.341 \\
\hline \multirow[t]{3}{*}{ Combined $(0-8$ weeks $) 1$} & 1 & $214.7^{3}$ & $173.4^{\mathrm{b}}$ & 4.24 & 1.238 \\
\hline & $\hat{2}$ & $214.9^{\mathrm{a}}$ & $185.6^{\mathrm{b}}$ & 4.74 & 1.158 \\
\hline & 3 & $214.3^{a}$ & $167.4^{\mathrm{b}}$ & 5.45 & 1.281 \\
\hline
\end{tabular}

${ }^{a b}$ Means having different superscripts on the same row are significantly different $(P<0.05)$.

study. The performance fof the male and female broilers to the diets at the starter (0-4 weeks) and finisher (5-8 weeks) phases respectively gave a farily different picture. While both sexes separately performed better on Diet 2 than any of the other diets in the 0-8 weeks growing period, at the starter phase male recorded more weight gains on Diet 3 and the female on Diet 2 (Table 3). Both sexes had the highest weight gains on Diet 2 . during the finisher phase. These results showed that female broilers performed better at both the starter and finisher phases on high energy diets, while males would harmlessly tolerate low energy diets at the starter phase but a high energy one at the finishing period, typical of the conventional broiler rations. The tring-rm high energy diet is therefore mone appregrite for female broilers while the conventional diet is adequate for the males. Male broilers grew more uniformly than females, hence recorded less coefficient of variation (C.V.) in average body weights (14.4 versus $17.4 \%$ ). The C.V. value computed for birds on the three diets were 16.6, 16.0 and $15.3 \%$ respectively, thereby giving preference to the conventional diet (Diet 3 ).

\section{Effect of Location}

Differences in body weight gains between male and female broilers in either of the two locations - cage or floor-were highly significant $(P<0.01)$. The males gained slightly more body weight in the cage than on the floor while the females performed better on the floor than in the cage (Table 4) during the $0-8$ weeks growing period. Consequent to this, the male: female DR was smaller on the floor than in the cange. The floor would therefore be preferred 


\section{TABLE 4: BODY WEIGHT GAINS AND MALE/FEMALE DIVERGENCE RATIOS OF BROILERS AT CIFFERENT LOCATIONS AND GROWING PHASES.}

\begin{tabular}{|c|c|c|c|c|c|}
\hline \multirow[b]{2}{*}{ Phase } & \multirow[b]{2}{*}{ Location } & \multicolumn{3}{|c|}{ Mean body weight gains (g/bird/wk) } & \multirow[b]{2}{*}{ D.R } \\
\hline & & Male & Femate & S.E. & \\
\hline Starter & Cage & 135.2 & 116.9 & 10.97 & 1.157 \\
\hline (0-4 weeks) & Fioor & 138.3 & 125.2 & 10.89 & 1.105 \\
\hline Finisher & Cage & $294.7^{7}$ & $231.9^{6}$ & 7.59 & 1.271 \\
\hline ( $5-8$ weeks) & Floor & $290.3^{3}$ & $227.8^{b}$ & 11.70 & 1.274 \\
\hline Combined & Cage & $215.0^{\mathrm{a}}$ & $174.4^{b}$ & 3.84 & 1.233 \\
\hline (0-8 weeks) & Floor & $214.3^{\mathrm{a}}$ & $176.5^{\mathrm{b}}$ & 4.10 & 1.214 \\
\hline
\end{tabular}

ab Mean having diffrent superscripts on the same row are significantly different $(P<0.05)$

TABLE 5: EFFECTS OF DIET AND LOCATION ON FEED INTAKE AND UTILIZATION

\begin{tabular}{|c|c|c|}
\hline Treatments & Feed intake ( $\mathrm{g} / \mathrm{bird} / \mathrm{day})$ & Feed utilisation \\
\hline \multicolumn{3}{|l|}{ Diet } \\
\hline 1 & $68.9^{3}$ & $2.45^{i}$ \\
\hline 2 & $60.1^{\text {its }}$ & $2.310^{\mathrm{h}}$ \\
\hline 3 & $6.5 .1^{\mathrm{b}}$ & $2.27^{\mathrm{h}}$ \\
\hline S.E. & 1.08 & 0.06 \\
\hline Location & $\cdot$ & \\
\hline Cage & $69.4^{a}$ & 2.38 \\
\hline Floor & $64.5^{b}$ & 2.31 \\
\hline S.E & 0.88 & 0.05 \\
\hline
\end{tabular}

for raising broilers when they are of mixed-sexes as it is conventionally practised in most parts of Nigeria. In earlier reports where cage had proved superior to the floor (Rajmane and Kulkarni, 1985; Ulmek, 1986), the male broilers must have contributed tremendously in terms of body weight gains. Considering the starter and finisher phases separately, both sexes recorded higher weight gains on the floor at the starter phase and higher gains in the cage at the finisher phase (Table 4). Birds in the cage recorded lower coefficient of variation in body weight than those on the floor (15.2 Vs. $16.7 \%$ ) thereby indicating more uniform growth in the cage than floor. Where available, therefore, cage would be the location of preference at the finisher stage for more weight gains.

\section{Feed intake and utilization}

Feed intake progressively increased with age. This was expected and agrees with the report of Hulan and Prodfoot (1982) and
Hulan et al. (1982). Older and heavier birds normally demand more feed for body maintenance. Consumption of Diet 1 was significantly $(P<0.05)$ more than diet 3 (Table 5) which had higher energy at the finisher phase. The later was significantly $(\mathrm{P}<0.05)$ better utilised than the former. These agree with the reports of Olomu (1976) Reece $e t$ al. (1984), Mendes and Cury (1986). The broilers significantly consumed more feed in the cage than the floor, while utilization of the feed was better though not significantly different $(P>0.05)$ on the floor than the cage.

In effect, male broilers grew more uniformly in average body weight with correspondingly lower coefficient of variation and were significantly $(P<0.05)$ superior to the females in average body weight gains either on low or higher energy diets as well as the cage and floor locations. The male and female birds significantly $(P<0.05)$ consumed more feed in the cage than on the floor while 


\section{LASEINDE AND OLUYEMI}

utilization of the feed was better, $(P>0.05)$, on the floor than in the cage.

\section{REFERENCES}

BABATUNDE, G.M. AND B.L. FETUGA, (1976). Determination of the minimum crude protein requirements of broiler starter and finisher in the tropics. Nig. J. Anim Prod. 3(1): 126 - 138.

DEATON, J.W. and B.D. LOTT (1985). Age and dietary energy effect on broiler abdominal fat deposition. Poultry Sci. 64: 2161 - 2164.

HULAN, H.W. and F.G. PROUDFOOT (1982). The effect of dietary energy regimes on the performance of two commercial chicken - broiler genotypes reared to roaster weight. Poultry Sci. 61: 510 - 515.

HULAN, H.W. and PROUDPOOT, F.G. and RAMEY D. (1982). The performance of male broiler genotypes reared to roaster weight and females reared to broiler weight on a low protein dietary regimen. Poultry Sci. 61: 434 - 437

KESHRI, R.C, VERMA, S.S. SINHA, S.P, SHARMA, R.P. SHINGH P.B, ROY A.K.D. and SHYMMSUNDER G. (1985). The relationship between live weight and evisceration yield in pure bred broiler strains. Indian J. of Poultry Sci. 20 (4) 297 - 299. In: Poultry Abstr. (1986) 12 (15) 126.

LEESON, S. and SU,ERS J.D. (1985). Effect of cage versus floor rearing and skip-a-day versus everyday feed restriction on the performance of dwarf broiler breeders and their offsprings. Poultry Sci. 64: 1742 - 1749.

MARKS, H.L. (1985). Sexual dimorphism in the early feed and water intake of broilers. Poultry Sci. 64: 425 - 428.

MARKS, H.L. (1986). The role of water intake on sexual dimorphism for early growth of broilers. Poultry Sci. 65: $433-435$

MARKS, H.L. (1987). Sexual dimorphism in broilers following periods of equal water and feed intake. Poultry Sci. 66: 381 - 389.

MENDES, A.A. and CURRY P.R. (1986). Effects of dietary enery levels and sex on broiler performance and carcass - 7th European Poultry Conference, Paris, 1986. Vol 1. General,. Genetics, Nutrition, Posters. Ed. by M. Letier pp. 543 - 547.

MENDOCA Jr. C.X. DE (1983). Effect of the amount of energy in the diet on performance and carcass yiekds of broiler chickens. Revista de faculdade de Medicina Veterinaria e Zoo tecnia da Universidade de San Paulo (1933) 20 (2) 161 - 175. In: Poultry Abst. (1986) 12 (4) 102: 862 .
OLOMU, J.M. (1976). Determination of optimum protein and energy levels for broiler chicks in the tropics. Nig. $\mathrm{J}$. of Anim. Prod. 3(1) 177 - 183.

PANDEY, N.K MAHAOATRA, C.M, GOYAL, R.C. and VERMA, SS, (1985). Carcass yeilds, quality and meat composition of broiler chickens as influenced by strain, sex and age. Indian J. of Anim. Sci. 55: 371 - 380.

POLANCO, G. and VIGI, E. (1984). Effect of housing density on broilers reared in cages. In: Poultry Abst. (1986) 12 (3) 40: 332.

RAJMANE, B.V. and KULKARNI, M.V. (1985). Effect of combination of energy levels and housing system on some economic traits in broiler. Poultry Adviser 18: 29 $-32$.

REECE, F.N. LOTT, B.D. and DEATON,J.W. (1984). The effect of feed form, protein profile, energy levels and gender on broiler performance in warm $\left(26.7^{\circ} \mathrm{C}\right)$ environment. Poultry Sci. 63: 1906 - 1911.

SHARMA, R.P., MOHAPATRA, S.C., SINGH, B.P., ROY A.K.D., JOHARI, D.C., and GARG R.C., (1983). Effects of strain, sex and year on growth and conformation traits in four broiler populations. Avian Res. $67(2) 43-47$.

SNEDECOR, G.W. and COCHRAN, W.R. (1976) Statistical methods, 6th Ed. Iowa State Univ. Press, Ames, Iowa, USA.

SUMMERS, J.D. and LEESON S. (1984). Influence of dietary protein and energy level on broiler performance and carcass composition. Nutrition Reports Intemational 29: 757 - 767 .

THANGARAJU, P. RAHUMATHULLAH, P.S., and MATARAJAN. N., (1983). Influence of sex on the growth patterns of white leghor chicks Res. 67 (3) 104 105.

ULMEK, B.R. (1986). Effect of housing system and feeding on day old white leghotn male chicks. Poultry Adviser 19: 45 - 47 .

VERMA, S.K SHRIVASTOV, A,K., SAHAY, B.N. and PRASAD, A. (1983). Studies on the relationship between breast width and body weight during growing period in WL X RIR. Crossbred chickens. Avian Res. 67(2) $64-65$.

WHITING, T.S. and PEST, G.M., (1983). Effects of the dwarfing gene (dw) on egg weight, duck weight and chick weight: egg weight ratio in a commercial broiler strain. Poultry Sci. 62: 2297 - 2302 